\title{
Modeling biological nitrogen fixation in global natural terrestrial ecosystems
}

\author{
Tong Yu ${ }^{1}$ and Qianlai Zhuang ${ }^{1,2}$ \\ ${ }^{1}$ Earth, Atmospheric, and Planetary Sciences, Purdue University, West Lafayette, IN 47907, USA \\ ${ }^{2}$ Department of Agronomy, Purdue University, West Lafayette, IN 47907, USA
}

Correspondence: Qianlai Zhuang (qzhuang@purdue.edu)

Received: 11 July 2019 - Discussion started: 6 August 2019

Revised: 20 May 2020 - Accepted: 17 June 2020 - Published: 13 July 2020

\begin{abstract}
Biological nitrogen fixation plays an important role in the global nitrogen cycle. However, the fixation rate has been usually measured or estimated at a particular observational site. To quantify the fixation amount at the global scale, process-based models are needed. This study develops a biological nitrogen fixation model to quantitatively estimate the nitrogen fixation rate by plants in a natural environment. The revised nitrogen module better simulates the nitrogen cycle in comparison with our previous model that has not considered the fixation effects. The new model estimates that tropical forests have the highest fixation rate among all ecosystem types, which decreases from the Equator to the polar region. The estimated nitrogen fixation in global terrestrial ecosystems is $61.5 \mathrm{Tg} \mathrm{N} \mathrm{yr}^{-1}$ with a range of $19.8-107.9 \mathrm{Tg} \mathrm{N} \mathrm{yr}^{-1}$ in the 1990s. Our estimates are relatively low compared to some early estimates using empirical approaches but comparable to more recent estimates that involve more detailed processes in their modeling. Furthermore, the contribution of nitrogen made by biological nitrogen fixation depends on ecosystem type and climatic conditions. This study highlights that there are relatively large effects of biological nitrogen fixation on ecosystem nitrogen cycling. and the large uncertainty of the estimation calls for more comprehensive understanding of biological nitrogen fixation. More direct observational data for different ecosystems are in need to improve future quantification of fixation and its impacts.
\end{abstract}

\section{Introduction}

In most terrestrial ecosystems, nitrogen $(\mathrm{N})$ available for plants is generally limited, although it is the most abundant element in the atmosphere (LeBauer and Tresder, 2008). Nitrogen usually enters terrestrial ecosystems through processes of nitrogen deposition and from biological $\mathrm{N}$ fixation (BNF). Nitrogen deposition is a physical process, representing the direct input of reactive nitrogen including organic $\mathrm{N}$, ammonia and nitrogen oxides $\left(\mathrm{NO}_{y}\right)$ including nitric oxide (NO), nitrogen dioxide $\left(\mathrm{NO}_{2}\right)$, nitric acid $\left(\mathrm{HNO}_{3}\right)$ and organic nitrates from the atmosphere to biosphere. BNF, a biochemical process that converts nonreactive nitrogen $\left(\mathrm{N}_{2}\right)$ to reactive nitrogen, provides a liaison between the atmosphere and biological systems. Lightning is also a way to convert $\mathrm{N}_{2}$, adding 3-5 $\mathrm{Tg} \mathrm{Nyr}^{-1}$ to terrestrial ecosystems (Levy and Moxim, 1996). Nitrogen input via rock weathering is another important source for terrestrial ecosystems, adding 3-10 $\mathrm{kg} \mathrm{Nha}^{-1} \mathrm{yr}^{-1}$ (Morford et al., 2011; Houlton et al., 2018). BNF is significantly greater than lightning-induced $\mathrm{N}$ fixation (Galloway et al., 1995). On a global scale, anthropogenic nitrogen in the environment could be more than $160 \mathrm{Tg}$ N yr-1 (Gruber and Galloway, 2008), which is even greater than terrestrial $\mathrm{N}$ fixation $\left(\sim 110 \mathrm{Tg} \mathrm{N} \mathrm{yr}^{-1}\right)$. However, taken together, natural $\mathrm{N}$ fixation is the primary source of global terrestrial ecosystems in the absence of human activities. For natural terrestrial ecosystems, the amount of $\mathrm{N}$ added is approximately balanced by the nitrogen converted back to the atmosphere (Stedman and Shetter, 1983) and lost into ocean and other aquatic systems.

Once entering terrestrial ecosystems, $\mathrm{N}$ can be taken up by plants and microbes and converted into other oxidized forms 
through mineralization, nitrification and denitrification. In terrestrial ecosystems, $\mathrm{N}_{2}$ fixation generally affects the nitrogen cycle and nutrient level to constrain plant productivity. Any change in nitrogen input to terrestrial ecosystems will influence their soil nitrogen content.

In the process of BNF, $\mathrm{N}_{2}$ is converted to ammonia by certain soil microorganisms, which can then be utilized by and incorporated into plants. In a natural environment, $\mathrm{N}_{2}$ fixation is conducted by two types of microorganisms: asymbiotic organisms and symbiotic organisms. The former includes blue-green algae, lichens and free-living soil bacteria (Belnap, 2002; Granhall and Lid-Torsvik, 1975), and the later includes fungi and nodule-forming Rhizobium species. Among them, the most dominant fixers are leguminous plants, and their $\mathrm{N}$ fixation mechanisms are also the best known (Sullivan et al., 2014; Vitousek et al., 2013). A symbiotic relationship exists between legume plants and bacteria, in which legume plants provide the bacteria with energy through photosynthesis. and the bacteria around the rhizobia supply the legume with $\mathrm{N}$ in the form of ammonia. To date, the amount of $\mathrm{N}$ fixation by legumes is estimated to be in the range of $11.3-33.9 \mathrm{~kg} \mathrm{Nha}^{-1} \mathrm{yr}^{-1}\left(2.8 \sim 8.4 \mathrm{~g} \mathrm{~m}^{-2} \mathrm{yr}^{-1}\right)$ in natural terrestrial ecosystems.

The biological $\mathrm{N}_{2}$ fixation rate has been usually measured or estimated at a particular observational site. To quantify the fixation amount at the global scale, process-based models and sufficient observational data are needed. This study develops a BNF model considering the symbiotic relationship between legume plants and bacteria. The model is extensively calibrated with site-level observational data. The model is then extrapolated to the global terrestrial ecosystems to quantify the fixation rate in the 1990s. The factors influencing the fixation rate are also analyzed for different terrestrial ecosystems, including the distribution of legume plants, soil temperature, and soil properties and types.

\section{Methods}

\subsection{Overview}

We first develop a BNF model and then couple the model with an earlier version of a biogeochemistry model quantifying soil carbon and nitrogen dynamics (Yu and Zhuang, 2019). The revised model is then used to quantify the BNF at regional and global scales in natural terrestrial ecosystems. The BNF rate estimates consider the effects of environmental conditions including temperature, soil moisture, soil mineral nitrogen content and soil carbon content. The modified model is calibrated and evaluated with observed $\mathrm{N}_{2}$ fixation rate data from published studies for various natural terrestrial ecosystems from the Arctic to tropical ecosystems. The model sensitivity to model input is analyzed. The model is then extrapolated to the global terrestrial ecosystems at a monthly time step and a spatial resolution of $0.5^{\circ}$ by $0.5^{\circ}$ for the final decade of the 20th century. The effects of physical conditions on BNF are then analyzed.

\subsection{Model description}

The Terrestrial Ecosystem Model (TEM) is a process-based model that simulates carbon and nitrogen dynamics and hydrological and thermal processes for terrestrial ecosystems. Although many efforts were made to incorporate more details of the $\mathrm{N}$ cycle, the $\mathrm{N}$ input from the atmosphere to ecosystems has not fully been incorporated to date, especially the BNF as input. Here we improve the $\mathrm{N}$ dynamics within TEM by considering $\mathrm{N}_{2}$ fixation by legumes. The model schematic and other calculations including the carbon cycle and the nitrogen cycle are inherited from an earlier version of TEM (Zhuang et al., 2003; Yu and Zhuang, 2019).

BNF is the most significant process in either symbiotic or non-symbiotic forms, converting stable molecular $\mathrm{N}_{2}$ into $\mathrm{N}$ chemical compounds that are available to plants. For most terrestrial ecosystems, $\mathrm{N}_{2}$ fixers could exist in many forms, such as free-living bacteria, lichens and blue algae. But among them, symbiotic BNF is a dominant process to provide biologically accessible $\mathrm{N}$, and most systematical BNF is regulated by legume plants, especially in croplands and seminatural environments (Mus et al., 2016). In natural environments, contributions from legumes can be significant but with large uncertainties, which is greatly determined by various environmental conditions (Lindemann and Glover, 1996). In this study, the $\mathrm{N}_{2}$ fixation via legume plants is modeled considering (1) the accessible $\mathrm{N}$ concentration in soils, (2) the limitation of temperature, (3) soil water status, (4) the carbon demand for $\mathrm{N}_{2}$ fixation and (5) the percentage of $\mathrm{N}_{2}$ fixing plants for each ecosystem type as

$\mathrm{N}_{\text {fix }}=\mathrm{N}_{\text {fixpot }} f_{\mathrm{t}} f_{\mathrm{W}} f_{\mathrm{N}} f_{\mathrm{C}} f_{\text {plant }}$,

where $\mathrm{N}_{\text {fix }}$ is the nitrogen fixation rate, $\mathrm{N}_{\text {fixpot }}$ is the potential $\mathrm{N}_{2}$ fixation rate $\left(\mathrm{g} \mathrm{N} \mathrm{d}^{-1}\right), f_{\mathrm{t}}$ is the influence function of soil temperature, $f_{\mathrm{W}}$ is the soil water function, $f_{\mathrm{N}}$ is the function of root substrate $\mathrm{N}$ concentration, $f_{\mathrm{C}}$ is the function of plant carbon availability and $f_{\text {plant }}$ is the function of legume plant coverage. Please refer to Table 4 for the value range of related parameters.

The potential $\mathrm{N}_{2}$ fixation is highly related to the total $\mathrm{N}$ demand of plants and the available nitrogen in soils. Theoretically, the definition of the potential $\mathrm{N}_{2}$ fixation rate should be the difference between the demand and supply of N. Both of them vary with plant types, stages of growth and soil conditions. For large spatial-scale simulations for various ecosystem types, it is impossible to derive potential $\mathrm{N}_{2}$ fixation because of data availability. $\mathrm{N}_{\text {fixpot }}$ can be estimated based on root, nodule or plant dry matter (Voisin et al, 2003, 2007). However, root biomass is also difficult to measure directly. In most published studies, the potential nitrogen fixation rate was measured using an acetylene reduction array (ARA) method (Hardy et al, 1968, 1973), and some researchers used 
${ }^{15} \mathrm{~N}$ methods (Shearer and Kohl, 1986). In our simulation, $\mathrm{N}_{\text {fixpot }}$ is assumed to be a constant for each ecosystem type. The $\mathrm{N}_{\text {fixpot }}$ range is determined from the literature, and specific values for various ecosystem types are obtained through model parameterization.

Soil temperature is a controlling factor for both microbial activities and plant growth. A large number of studies show that different plants have slightly different preferences for temperature (Montanez et al, 1995; Breitbarth et al., 2007; Gundale et al., 2012). For soybean, $20-35^{\circ} \mathrm{C}$ is optimal (Boote et al., 2008), and for white clover the optimal temperature can be $13-26^{\circ} \mathrm{C}$ (Wu and McGechan, 1999). The activity of microbes responds slightly differently to temperature among species. For most of them, the optimum temperature is $20-25^{\circ} \mathrm{C}$, and at $12-35^{\circ} \mathrm{C}$ the activity is not limited. Generally, the relation between the factor and temperature is not exactly a Gaussian distribution. BNF increases as the temperature rises from a minimum temperature $\left(0-5^{\circ} \mathrm{C}\right)$ for $\mathrm{N}$ fixation to the optimal temperature; the maximum rate occurs within an optimal range $\left(15-25^{\circ} \mathrm{C}\right)$ and decreases from the optimal to the maximum temperature, above which BNF will stop at $35-40^{\circ} \mathrm{C}$ :

$f_{t}=\left\{\begin{array}{cc}\frac{t-t_{\min }}{t_{\mathrm{optL}}-t_{\min }} & \text { when }\left(t<t_{\min } \text { or } t>t_{\mathrm{max}}\right) \\ \frac{t_{\max }-t}{t_{\max }-t_{\mathrm{optH}}} & \text { when }\left(t_{\mathrm{optL}} \leq t \leq t_{\mathrm{optH}}\right) \\ \text { when }\left(t_{\mathrm{optH}}<t \leq t_{\max }\right)\end{array}\right.$,

where the upper limit $\left(t_{\max }\right)$ is set to $45^{\circ} \mathrm{C}$. There is no lower limit, but when $t$ is low enough, $f_{\mathrm{t}}$ will be close to zero $(\mathrm{Wu}$ and McGechan, 1999; Boote et al., 2008; Holzworth et al., 2014) (Table 1). For convenience in computing, a lower limit is set in our model. When the temperature goes beyond its upper or lower limit, $f_{\mathrm{t}}$ is assumed to be 0 .

Water stress has a direct effect on the nitrogen-fixing system (Sprent, 1972). With proper temperature, the soil moisture condition is the major factor controlling the nitrogen fixation rate (Srivastava and Ambasht, 1994). Soil water deficit and flood dramatically inhibit $\mathrm{N}_{2}$ fixation because of drought stress and oxygen deficit, respectively (Omari et al., 2004; Marino et al., 2007). In our model, the water factor is linearly related to soil water content (Williams, 1990; Wu and McGachan, 1999):

$f_{\mathrm{w}}=\left\{\begin{array}{c}0 \text { when }\left(W_{\mathrm{f}} \leq W_{\mathrm{a}}\right) \\ \varphi_{1}+\varphi_{2} \text { when }\left(W_{\mathrm{a}}<W_{\mathrm{f}}<W_{\mathrm{b}}\right), \\ 1 \text { when }\left(W_{\mathrm{f}} \geq W_{\mathrm{b}}\right)\end{array}\right.$

where $W_{\mathrm{f}}\left(\mathrm{J} \mathrm{kg}^{-1}\right)$ is the available soil water, which is defined as the ratio of water content to that at the field capacity. In soils, water potential generally includes osmotic and matrix potentials, ranging from -0.1 to -0.3 bar for typical soils, which has little effect on $\mathrm{N}$ fixation. But when the soil gets very dry, the potential can be up to -100 to -200 bar and increases rapidly. $W_{\mathrm{a}}$ is the bottom threshold below which $\mathrm{N}_{2}$ fixation is totally restricted by soil moisture. $W_{\mathrm{b}}$ is the upper threshold above which nitrogen fixation is not limited by soil moisture. $\varphi_{1}$ and $\varphi_{2}$ are parameters representing the linear relationship between soil water content and its effect on $\mathrm{N}_{2}$ fixation, respectively (Table 1 ).

It is generally thought that more substrate $\mathrm{N}$ in soils will slow down the $\mathrm{N}_{2}$ fixation because plants can take up $\mathrm{N}$ directly from soil with less energy (Vitousek and Field, 1999). By comparison, $\mathrm{N}_{2}$ fixation needs more energy and consumes more carbon than plant $\mathrm{N}$ uptake does. Thus, the $\mathrm{N}_{2}$ fixation is only considered to occur when the direct $\mathrm{N}$ uptake from soil cannot meet the plant $\mathrm{N}$ demand. In our model, the inhibition effect of $\mathrm{N}$ is defined as Wu and McGehan (1999):

$f_{\mathrm{N}}=\left\{\begin{array}{c}1-f_{\mathrm{Nup}} \ln \left(1000-N_{\mathrm{s}}\right) \text { when }\left(N_{\mathrm{s}} \geq 0.001\right) \\ 1 \text { when }\left(N_{\mathrm{s}}<0.001\right)\end{array}\right.$,

where $f_{\text {Nup }}$ is a parameter related to legume biological $\mathrm{N}_{2}$ fixation and soil $\mathrm{N}$. $N_{\mathrm{S}}$ is the soil mineral $\mathrm{N}\left(\mathrm{g} \mathrm{N} \mathrm{m}^{-2}\right)$. BNF efficiency shows a natural logarithmic relation with the soil mineral $\mathrm{N}$.

$\mathrm{N}_{2}$ fixers get photosynthetic carbohydrate support from plants. Because the product of every unit of nitrogen fixed consumes a certain amount of carbon, the lack of carbon supply will inhibit the $\mathrm{N}_{2}$ fixation. The carbon cost per unit of fixed $\mathrm{N}_{2}$ varies widely depending on environmental conditions and ecosystem types. For example, the consumption of carbon is only 1.54 times of fixed $\mathrm{N}_{2}$ for cowpea (Layzell et al., 1979), and it can be 6.3 to 6.8 times for soybeans (Ryle et al., 1979). It is also related to the life cycle of plants. The carbon effect is modeled following a Michaelis-Menten equation (Boote et al., 1998):

$f_{\mathrm{C}}=\frac{1}{1+K_{\mathrm{c}} / \mathrm{C}_{\mathrm{r}}}$,

where $\mathrm{C}_{\mathrm{r}}$ is the soil carbon content $\left(\mathrm{g} \mathrm{C} \mathrm{m}^{-2}\right)$ to represent carbon availability from plants to $\mathrm{N}_{2}$ fixers. $K_{\mathrm{c}}$ is the Michaelis-Menten constant, which is plant species dependent.

\subsection{Data}

The classification of land cover and leguminous biomes were derived from the combination of the International Geosphere and Biosphere (IGP) land cover classification system and the study of Schrire et al. (2005). The experimental $\mathrm{N}_{2}$ fixation data for model calibration were collected for 7 major ecosystem types. Nitrogen fixation rates were determined with the ARA method in most published studies (Table 2; data were from Cleveland et al., 1999), expressed in kilograms of $\mathrm{N}$ per square meter per year. Some of them were measured with the ${ }^{15} \mathrm{~N}$ natural abundance technique.

The parameters for the $\mathrm{N}_{2}$ fixation module were initialized with a priori values (Table 2). Ecosystem-specific and microbe guild-specific parameters were inherited from a previous TEM model (Zhuang et al., 2003; Yu and Zhuang, 2019). 
Table 1. Description of parameters used in the model.

\begin{tabular}{|c|c|c|c|c|}
\hline Parameters & Description & Unit & Reference value & reference \\
\hline $\mathrm{N}_{\mathrm{f}} \mathrm{ix}$ & nitrogen fixation rate & $\mathrm{gN} \mathrm{m}^{-2} \mathrm{~d}^{-1}$ & & \\
\hline $\mathrm{N}_{\mathrm{f}}$ ixpot & potential nitrogen fixation rate & $\mathrm{g} \mathrm{N} \mathrm{m}^{-2} \mathrm{~d}^{-2}$ & $0.01-1 \times 10^{-3}$ & $\begin{array}{l}\text { Thornley (2001), } \\
\text { Eckertsten et al. (2006), } \\
\text { Corre-Hellou et al. (2007, 2009) }\end{array}$ \\
\hline$f_{\mathrm{t}}$ & soil temperature factor & ${ }^{\circ} \mathrm{C}$ & & \\
\hline$t_{\min }$ & $\begin{array}{l}\text { the minimum temperature for the start } \\
\text { of } \mathrm{N} \text { fixation }\end{array}$ & ${ }^{\circ} \mathrm{C}$ & $0.5 \sim 5$ & Boote et al. (2008) \\
\hline$t_{\max }$ & $\begin{array}{l}\text { the maximum temperature for the stop } \\
\text { of } \mathrm{N} \text { fixation }\end{array}$ & ${ }^{\circ} \mathrm{C}$ & $40 \sim 45$ & Boote et al. (2008) \\
\hline$t_{\mathrm{OptL}}$ & lower threshold of optimal temperature & ${ }^{\circ} \mathrm{C}$ & $10 \sim 20$ & Boote et al. (2008) \\
\hline$t_{\mathrm{optH}}$ & upper threshold of optimal temperature & ${ }^{\circ} \mathrm{C}$ & $25 \sim 35$ & Boote et al. (2008) \\
\hline$f_{\mathrm{W}}$ & soil water factor & & & \\
\hline$\varphi_{1}$ & coefficient for soil moisture & & 0 & \\
\hline$\varphi_{2}$ & coefficient for soil moisture & & 2 & $\begin{array}{l}\text { APSIM, EPIC } \\
\text { (Sharpley and Williams, 1990; } \\
\text { Bouniols et al., 1991; } \\
\text { Cabelguenne et al., 1999); } \\
\text { SOILN (Wu and McGechan, 1999) }\end{array}$ \\
\hline$W_{\mathrm{a}}$ & $\begin{array}{l}\text { lower threshold of water content below } \\
\text { which } \mathrm{N} \text { fixation is totally restricted } \\
\text { by the deficit of soil water }\end{array}$ & & 0 & $\begin{array}{l}\text { APSIM, EPIC } \\
\text { (Sharpley and Williams, 1990; } \\
\text { Bouniols et al., 1991; } \\
\text { Cabelguenne et al., 1999); } \\
\text { SOILN (Wu and McGechan, 1999) }\end{array}$ \\
\hline$W_{\mathrm{b}}$ & $\begin{array}{l}\text { upper threshold of water content above } \\
\text { which } \mathrm{N} \text { fixation is not limited by the } \\
\text { deficit of soil water }\end{array}$ & & 0.5 & $\begin{array}{l}\text { APSIM, EPIC } \\
\text { (Sharpley and Williams, 1990; } \\
\text { Bouniols et al., 1991; } \\
\text { Cabelguenne et al., 1999); } \\
\text { SOILN (Wu and McGechan, 1999) }\end{array}$ \\
\hline$W_{\mathrm{f}}$ & $\begin{array}{l}\text { ratio of available soil water content to } \\
\text { that } \\
\text { at field capacity }\end{array}$ & & & \\
\hline$f_{\mathrm{Nup}}$ & $\begin{array}{l}\text { parameter relating legume biological } \\
\text { nitrogen fixation and soil } \\
\text { nitrogen content }\end{array}$ & & $0.01 \sim 0.1$ & $\begin{array}{l}\text { SOILN model } \\
\text { (Wu and McGehan, 1999) }\end{array}$ \\
\hline $\mathrm{N}_{\mathrm{s}}$ & soil mineral nitrogen content & $\mathrm{g} \mathrm{N} \mathrm{m}^{-2}$ & & \\
\hline$f_{\mathrm{N}}$ & soil mineral $\mathrm{N}$ effect & & & \\
\hline$f_{\mathrm{C}}$ & soil carbon effect & & & \\
\hline $\mathrm{C}_{\mathrm{r}}$ & carbon concentration in the soil & $\mathrm{gCg}^{-1}$ soil & & \\
\hline$K_{\mathrm{c}}$ & Michaelis-Menten constant for carbon & $\mathrm{gC} \mathrm{m}^{-2}$ & $0.001 \sim 0.01$ & $\begin{array}{l}\text { Thornley (2001), } \\
\text { Eckertsten et al. (2006) }\end{array}$ \\
\hline
\end{tabular}




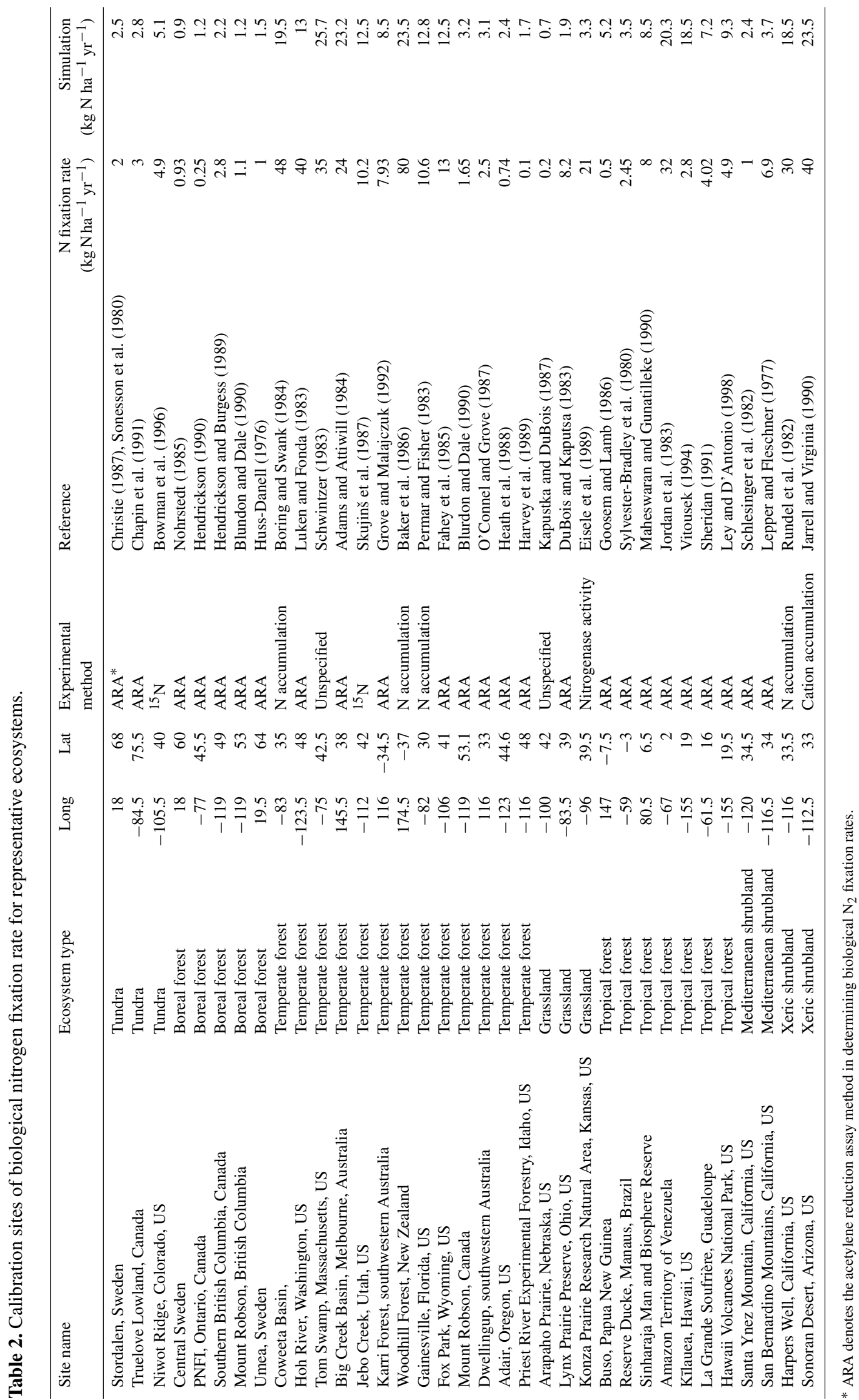


The global simulations were conducted at a spatial resolution of 0.5 by $0.5^{\circ}$ and at a monthly time step. Historical climate data including temperature, precipitation, cloudiness and water vapor pressure were derived from the Climate Research Unit (CRU) (Mitchell and Jones, 2005). Soil texture data were from Melillo et al. (1993) and Zhuang et al. (2003). Other initial conditions including vegetation properties, soil carbon content and soil nitrogen contents were from Chen and Zhuang (2013) and Zhuang et al. (2012).

For regional simulations, the total amount of fixed $\mathrm{N}_{2}$ was also influenced by legume coverage. For each ecosystem type, we estimated the coverage according to the distribution of legume plants and field studies (Table 3; the coverage data are compiled from Cleveland et al., 1999), where the minimum and maximum values were derived from the abundance of $\mathrm{N}_{2}$ fixers.

\subsection{Model calibration and site-level validation}

Most model parameters are legume-specific or vegetationspecific and are adjusted based on value ranges from previous studies (Table 1). Model is parameterized for seven representative natural terrestrial ecosystems (Table 2). Root mean square error (RMSE) and coefficient of determination $\left(0 \leq R^{2} \leq 1\right)$ were used for model calibration. RMSE was calculated to show the mean difference between simulated data and observational values. The model is iterated with changing parameters until the RMSE reached a certain value for each site. Most parameters in the model driving the nitrogen cycle in the soil have been defined and calibrated in previous studies (Yu and Zhuang, 2019). The calibrated model is evaluated at the site level and then extrapolated to the global terrestrial ecosystems.

\subsection{Model sensitivity and uncertainty analysis}

The response of $\mathrm{N}_{2}$ fixation of different biomes to input data and variation in parameters was analyzed using sensitivity testing. Four major input variables were selected, including air temperature, precipitation, soil nitrogen content and soil organic carbon content. The monthly average input variables were changed by $\pm 10 \%$ of the original level for each site and each grid. The variables were changed at six levels, and the rest of the input variables were kept at their original values. The sensitivity was calculated by comparing the simulated annual nitrogen fixation to the simulations with the original input values.

\section{Results}

\subsection{Model evaluation}

To evaluate the model, 35 observational sites were selected for seven major ecosystem types across the globe, representing different climate and soil conditions. The experimental

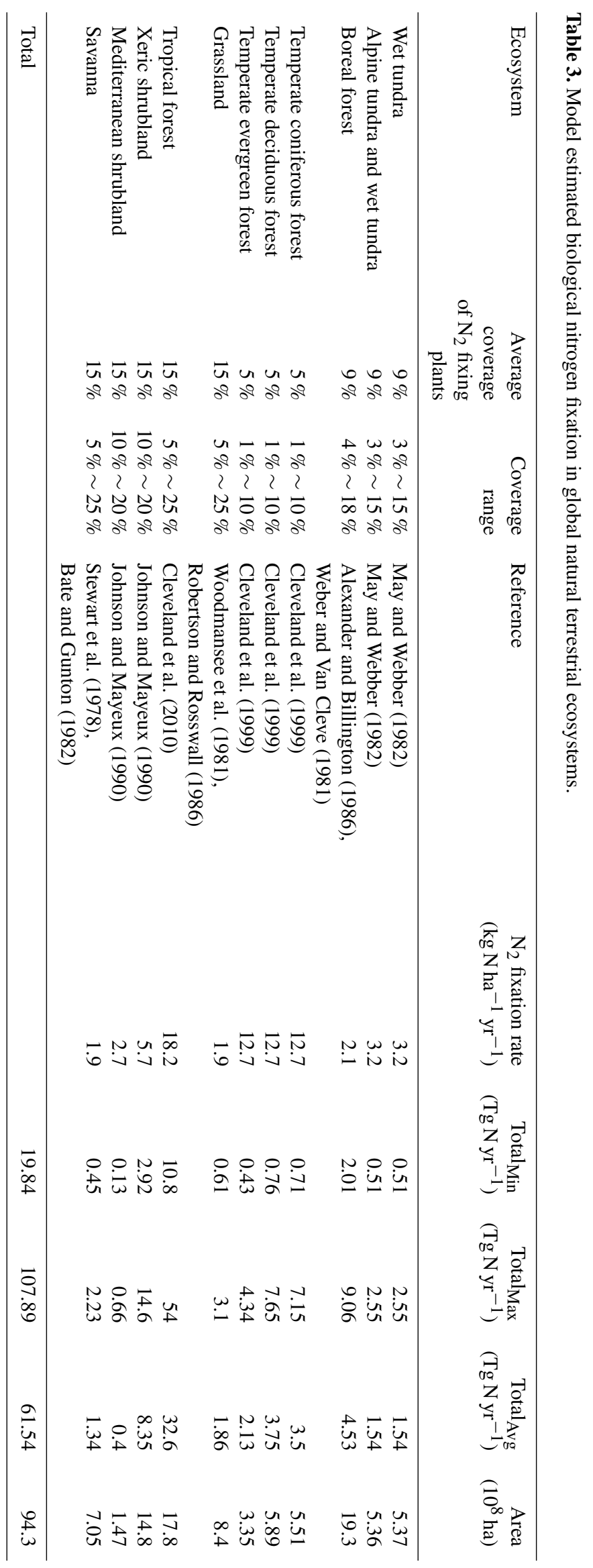

https://doi.org/10.5194/bg-17-3643-2020 
Table 4. Model parameters for various natural terrestrial ecosystems.

\begin{tabular}{|c|c|c|c|c|c|c|c|}
\hline & & $\left.\begin{array}{r}N_{\text {pot }} \\
\left(\mathrm{g} \mathrm{N}_{2} \text { fixed d }\right. \\
-1\end{array}\right)$ & $\begin{array}{l}t_{\mathrm{optL}} \\
\left({ }^{\circ} \mathrm{C}\right)\end{array}$ & $\begin{array}{r}t_{\mathrm{optH}} \\
\left({ }^{\circ} \mathrm{C}\right)\end{array}$ & $\begin{array}{r}W_{\text {upH }} \\
\left(\mathrm{J} \mathrm{kg}^{-1}\right)\end{array}$ & $f_{\text {Nup }}$ & $\begin{array}{r}K_{\mathrm{c}} \\
\left(\mathrm{gC} \mathrm{m}^{-2}\right)\end{array}$ \\
\hline 1. & Wet tundra & 0.028 & 10 & 25 & 0.8 & 65 & 0.002 \\
\hline 2. & Alpine tundra and wet tundra & 0.028 & 10 & 25 & 0.8 & 65 & 0.002 \\
\hline 3. & Boreal forest & 0.032 & 12 & 25 & 0.8 & 70 & 0.008 \\
\hline 4. & Temperate coniferous forest & 0.55 & 16 & 35 & 0.6 & 80 & 0.01 \\
\hline 5. & Temperate deciduous forest & 0.55 & 18 & 35 & 0.6 & 80 & 0.01 \\
\hline 6. & Temperate evergreen forest & 0.55 & 18 & 35 & 0.6 & 80 & 0.01 \\
\hline 7. & Grassland & 0.05 & 18 & 35 & 0.5 & 60 & 0.012 \\
\hline 8. & Tropical forest & 0.8 & 20 & 35 & 0.8 & 100 & 0.005 \\
\hline 9. & Xeric shrubland & 0.7 & 15 & 35 & 0.4 & 65 & 0.016 \\
\hline 10. & Mediterranean shrubland & 0.08 & 19 & 35 & 0.5 & 65 & 0.016 \\
\hline 11. & Savanna & 0.05 & 20 & 35 & 0.5 & 60 & 0.012 \\
\hline
\end{tabular}

data of $\mathrm{N}_{2}$ fixation have a mean value of $12.9 \mathrm{~kg} \mathrm{~N} \mathrm{ha}^{-1} \mathrm{yr}^{-1}$, with a standard deviation of $17.7 \mathrm{~kg} \mathrm{~N} \mathrm{ha}^{-1} \mathrm{yr}^{-1}$. The maximum observed fixation occurred in a temperate forest in New Zealand, while the minimum rate was also for a temperate forest in the state of Idaho in the US. Our simulations are comparable with the observed data for all major ecosystem types with the coefficient of determination $\left(R^{2}\right)$ of 0.44 and with a slope of 0.46 (Fig. 2). The regression results are mainly influenced by some observed data greater than $30 \mathrm{~kg} \mathrm{~N} \mathrm{ha}^{-1} \mathrm{yr}^{-1}$. By removing the outliers of observational data, the slope of regression increases to 0.72 . Observational data for temperate forests show the greatest variation among all major ecosystem types, with a maximum value reaching 800 times the minimum one. Simulations are closer to the observations across sites in temperate forests with $R^{2}$ of 0.26 and a slope of 0.42. Our model underestimated a nitrogen fixation rate in temperate forests. The large variation in observations may be due to the distribution of legume plants, different sampling time periods (e.g., growing and non-growing seasons) and varying climate conditions. For tropical forests, our model estimates of $\mathrm{N}_{2}$ fixation are higher than observations with a slope of 0.75 and $R^{2}$ of 0.44 .

\subsection{Model sensitivity analysis}

The model sensitivity analysis quantifies the impact of changes in forcing data on nitrogen fixation rate. Climate conditions including air temperature and precipitation and soil characteristics of nitrogen content and carbon content varied at three levels to examine the sensitivity. The response of nitrogen fixation rate emissions is quantified for each ecosystem type. The sensitivity test was conducted for all observational sites (Table 2). Temperature is the most sensitive variable (Fig. 1). Nitrogen fixation is more sensitive to the change in all forcing conditions. Increasing soil nitrogen results in a lower $\mathrm{N}_{2}$ fixation. Abundant soil nitrogen content inhibits BNF activity but stimulates nitrification and denitrification processes.

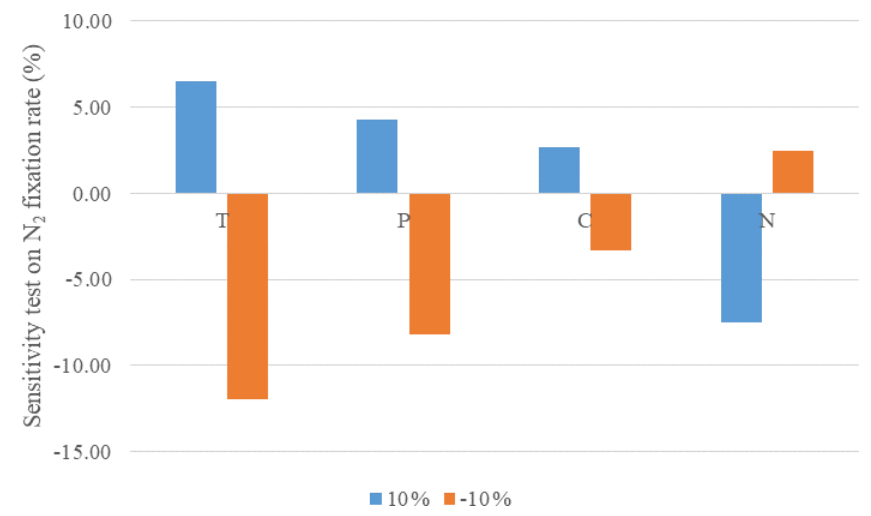

Figure 1. Model sensitivity of $\mathrm{N}_{2}$ fixation in natural terrestrial ecosystems to changing model input data: increasing or decreasing each variable by $10 \%$ for air temperature $(T)$, precipitation $(P)$, soil carbon content $(C)$ and soil nitrogen content $(\mathrm{N})$ for $\mathrm{N}_{2}$ fixation rate.

\subsection{Biological nitrogen fixation in global terrestrial ecosystems}

Tropical forests in South America, Central Africa and South Asia show a wide range of $\mathrm{N}_{2}$ fixation rates between 1 and $200 \mathrm{~kg} \mathrm{~N} \mathrm{ha}^{-1} \mathrm{yr}^{-1}$ (Bruijnzeel et al, 1991). Here all plants in tropical rainforest are assumed to fix nitrogen and one set of parameters is applied for all tropical forests. The coverage for tropical forests in the landscape was assumed to be $15 \%$ (Cleveland et al., 1999), ranging from $5 \%$ to $25 \%$. The $\mathrm{N}_{2}$ fixation rate was estimated to be $18.2 \mathrm{~kg} \mathrm{~N} \mathrm{ha}^{-1} \mathrm{yr}^{-1}$, which is the highest among all vegetation types. Our simulations show that the total fixed nitrogen ranges from 10.8 to $54 \mathrm{Tg} \mathrm{Nyr}^{-1}$, with an average value of $32.5 \mathrm{Tg} \mathrm{N} \mathrm{yr}^{-1}$ ( $\mathrm{Ta}-$ ble 3). Nitrogen fixation in tropical forests is almost half of the global total amount and a principal contributor of BNF in natural ecosystems. Tropical forests have the largest potential to fix nitrogen given that the optimal temperature and 
soil moisture for BNF is relatively easy to have under tropical climatic conditions.

Temperate forests cover the largest land area from 30 to $60^{\circ} \mathrm{N}$, including temperate coniferous forest, temperate deciduous forest and temperate evergreen forest. Temperate areas have the majority of legumes, and many temperate ecosystems are considered to be $\mathrm{N}$ limited. Compared to other ecosystem types in temperate regions, conifers are likely to limit the reproduction of legumes (Wheatley et al, 2009). In general, plant species carrying nitrogen fixers are only distributed in a small percentage of natural temperate forests, like clear-felled areas and pastures (Boring and Swank, 1984). Cleveland et al. (1999) indicated that the legume coverage ranges from $1 \%$ to $10 \%$ of the land area only. Consequently, our simulations indicate that $\mathrm{N}_{2}$ fixation by temperate forests was $12.7 \mathrm{~kg} \mathrm{Nha}^{-1} \mathrm{yr}^{-1}$. The estimates of the total nitrogen fixation were between 1.9 and 19.14 $\mathrm{Tg} \mathrm{N} \mathrm{yr}^{-1}$ (Table 3). Nitrogen fixation in temperate areas contributes $12.5 \%$ of the global total amount.

Savanna covers over a half of the African continent, Australia and large areas of South America. It is an important biome in the Southern Hemisphere. There is a great variation in native legume species. Only in humid savanna, may legumes significantly contribute to the increase in soil nitrogen (Cech et al., 2008). On average, $15 \%$ of the vegetation in the savanna is regarded as legume grass, and biological nitrogen fixation occurs when precipitation is greater than $10 \mathrm{~mm}$ per month. Generally, nitrogen fixation in the savanna is restricted by soil moisture, while temperate grassland is limited by both temperature and soil moisture (Bustamante et al., 2006). Nitrogen fixers are not abundant for these biomes (Woodmansee et al., 1981). The coverage of nitrogen fixers was assumed to be from $5 \%$ to $25 \%$, (Cleveland et al., 1999). Our simulation assumed that nitrogen fixers cover $15 \%$ of the land, resulting in $1.9 \mathrm{~kg} \mathrm{Nha}^{-1} \mathrm{yr}^{-1}$ fixation, representing a much smaller fraction compared to forest ecosystems. Total fixed nitrogen in grasslands appeared to range from 0.62 to $3.1 \mathrm{Tg} \mathrm{N} \mathrm{yr}^{-1}$, with an average of $1.86 \mathrm{Tg} \mathrm{N} \mathrm{yr}^{-1}$. For the savanna, the total contribution was less due to its relatively small area. The minimum, average and maximum values were estimated to be $0.45,1.34$ and $2.23 \mathrm{Tg} \mathrm{N} \mathrm{yr}^{-1}$, respectively.

In tundra and boreal forest regions, both host plants and their rhizobia are adapted to the environment with low temperature. The nitrogen fixation rate is extremely variable for boreal ecosystems. For tundra, the coverage was assumed to be $3 \%-15 \%$, and for boreal forest, the coverage was $4 \%-$ $18 \%$. But in general, the low temperature and permafrost conditions limit the activity of nitrogen fixers (Alexander, 1981). We estimated that tundra ecosystems fix nitrogen at $3.2 \mathrm{~kg} \mathrm{Nha}^{-1} \mathrm{yr}^{-1}$. Their total BNF was between 0.51 to $2.55 \mathrm{Tg} \mathrm{N} \mathrm{yr}^{-1}$ with an average of $1.54 \mathrm{Tg} \mathrm{N} \mathrm{yr}^{-1}$. In boreal forests, the fixation rate was much lower $\left(2.1 \mathrm{~kg} \mathrm{~N} \mathrm{ha}^{-1} \mathrm{yr}^{-1}\right)$ compared to temperate forests.
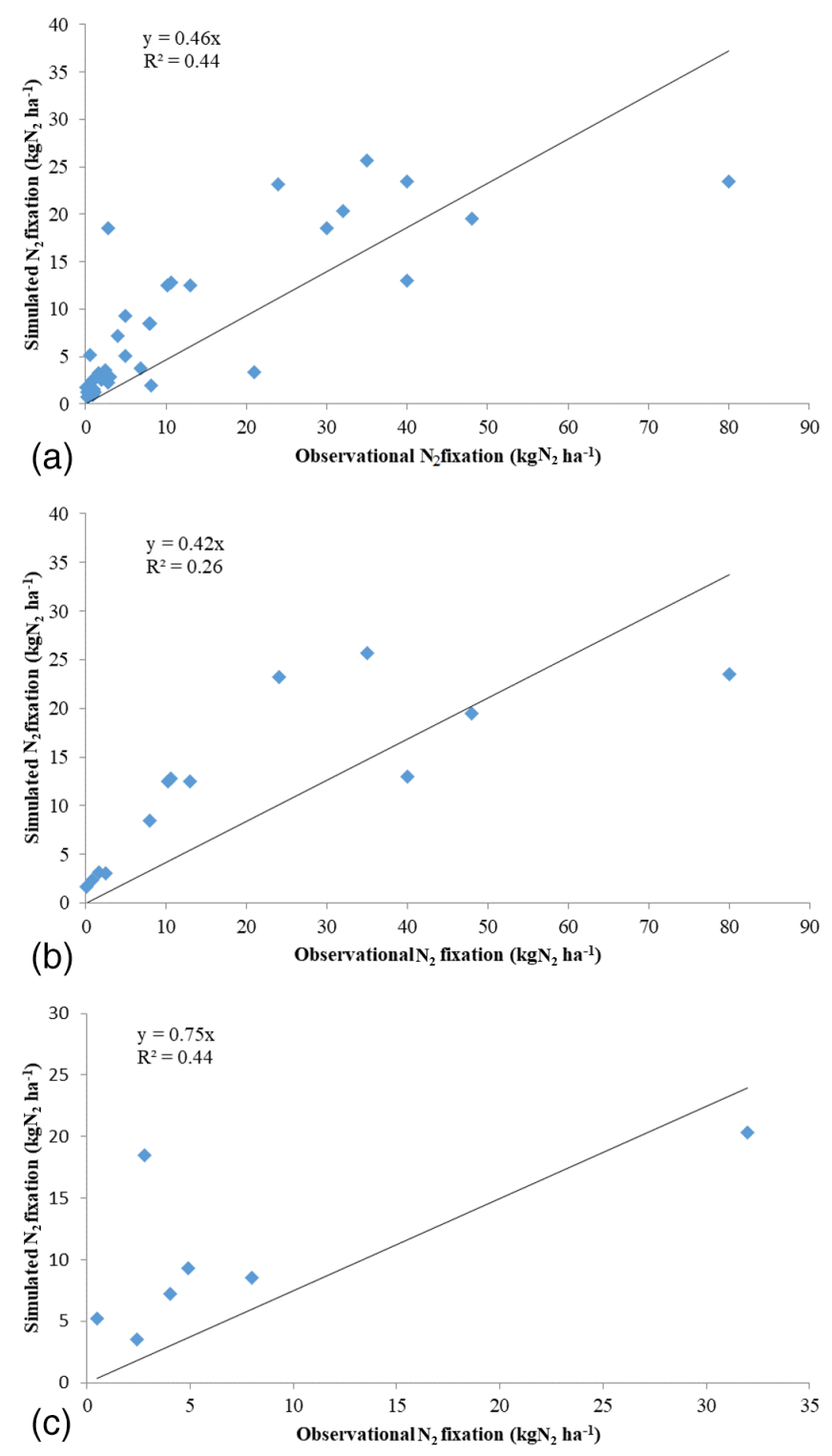

Figure 2. Comparison between modeled and observed nitrogen fixation rate at site level: (a) all sites, (b) temperate forest, (c) tropical forest (data listed in Table 2). The $y$ axis is simulated $\mathrm{N}_{2}$ fixation, while $x$ represents the observational $\mathrm{N}_{2}$ fixation.

The fixation could be neglected in deserts because of the extremely dry conditions. Only few legumes may exist in deserts, and their growth is highly depended on precipitation events. Even in semiarid areas, the $\mathrm{N}_{2}$ fixation rate is much lower than that in tropical and temperate forests $(5.7 \mathrm{~kg} \mathrm{~N}$ ha$\left.1 \mathrm{yr}^{-1}\right)$.

Mediterranean ecosystems such as in southern California and some areas in southern Australia are characterized with mild rainy winter and hot dry summer, containing both evergreen and deciduous shrublands, in which nodulated legumes are prominent (Sprent et al., 2017). These legumes are more active in a comparatively wet season than in a dry season 
(Sánchez-Diaz, 2001). The ability to fix nitrogen is considered to be one of the most important features that enable legumes and plants to survive under severe environments (Crisp et al., 2004). We estimated that the $\mathrm{N}_{2}$ fixation rate of these legume species is similar to that in grasslands $\left(2.7 \mathrm{~kg} \mathrm{Nha}^{-1} \mathrm{yr}^{-1}\right)$.

Spatially, the highest rate of $\mathrm{N}_{2}$ fixation occurred in the tropical and subtropical areas, as a result of proper climate and soil characteristics for fixers (Fig. 3). $\mathrm{N}$ fixation from tropical forests and xeric shrubland contributes to nearly half of the global terrestrial amount (Table 3). A lower $\mathrm{N}_{2}$ fixation rate was found in high latitudes of eastern China, North America and Europe, which were mainly covered with temperate forests. Compared to tropical areas, $\mathrm{N}_{2}$ fixation in temperate regions shows a larger variability depending on vegetation types. The spatial variation could be attributed to the distribution of legume plants, in addition to the difference in humidity and temperature conditions. $\mathrm{N}_{2}$ fixation in temperate regions accounts for $35 \%$ of the total fixed $\mathrm{N}_{2}$.

Our model estimated that high BNF rates in the growing season are consistent with other regional and global estimates (Cleveland et al., 1999, 2013; Lee and Son, 2005; Lett and Michelsen, 2014). The energetic cost for active $\mathrm{N}$ uptake becomes lowest when soil temperature is around $25^{\circ}$ (Fisher et al. 2010). Similarly, our estimates of high BNF rates also occur at similar temperature conditions in spring and summer. The global soil nitrogen mineralization rate was estimated to be $696 \mathrm{Tg} \mathrm{N} \mathrm{yr}^{-1}$, while $15 \%$ of plant $\mathrm{N}$ demand was provided by BNF (Cleveland et al., 2013). Our estimates of BNF were lower than the estimates by Cleveland et al. (2013) and fell within $10 \%$ of the total soil mineralization rate. This result also indicates that about $10 \%$ of the mineralized $\mathrm{N}$ was induced by BNF.

From 1990 to 2000, our simulations show that BNF in natural terrestrial ecosystems is $61.5 \mathrm{Tg} \mathrm{N} \mathrm{yr}^{-1}$, but anthropogenic $\mathrm{N}_{2}$ fixation was much higher at $140 \mathrm{Tg} \mathrm{N} \mathrm{yr}^{-1}$ (Galloway et al., 2002). This large amount of anthropogenic $\mathrm{N}$ input to terrestrial ecosystems is expected to inhibit the natural BNF and might lead to less BNF in the future.

\section{Discussion}

\subsection{Comparison with other estimates of biological nitrogen fixation (BNF)}

There is a large uncertainty in estimating the $\mathrm{N}$ input into terrestrial ecosystems, especially from BNF (Sutton et al., 2014) (Table 3). In our study, a calibrated process-based model was applied to estimate site-level and global BNF in natural terrestrial ecosystems. Empirical models provide a reasonable estimation based on relationships between $\mathrm{N}_{2}$ fixation rates and environmental factors (e.g., evapotranspiration) (Cleveland et al, 1999), while process-based approaches consider processes in BNF affected by multiple control- ling factors (Fisher et al., 2010; Gerber et al., 2008; Gerber et al., 2010). Our estimated BNF in the global terrestrial ecosystems is $61.5 \mathrm{Tg} \mathrm{N} \mathrm{yr}^{-1}$ with an uncertainty ranging from 19.8 to $107.9 \mathrm{Tg} \mathrm{Nyr}^{-1}$, which is lower than most existing studies. Cleveland et al. (1999) provided a central value of $195 \mathrm{Tg} \mathrm{N} \mathrm{yr}^{-1}$ by scaling up field-based experimental data, with a range of $100-289 \mathrm{Tg} \mathrm{N} \mathrm{yr}^{-1}$. This range represents potential distribution of nitrogen fixation. In reality, $\mathrm{N}_{2}$ fixation is also affected by climate and soil conditions, making the actual terrestrial BNF smaller than the potential one. In a more recent study of Cleveland et al. (2013), a total of $127.5 \mathrm{Tg} \mathrm{N} \mathrm{yr}^{-1}$ was estimated to be related to BNF, based on the relationship between BNF and evapotranspiration (ET). Galloway et al. (2002b) also provided several estimates for global BNF. Galloway et al. (2004) further suggested a range of $100-290 \mathrm{Tg} \mathrm{N} \mathrm{yr}^{-1}$ and implied that the true rate of BNF would be at the low end of this range without large-scale human disturbance. In an earlier study (Galloway et al., 2002b), the mean annual global BNF was estimated to be $89-100 \mathrm{Tg} \mathrm{Nyr}^{-1}$. By assuming a steady state between $\mathrm{N}$ input to and loss from ecosystems, Vitousek et al. (2013) estimated the BNF to be $58 \mathrm{Tg} \mathrm{N} \mathrm{yr}^{-1}$ with a plausible range of $40-100 \mathrm{Tg} \mathrm{N} \mathrm{yr}^{-1}$, which is similar to our estimates. However, Xu-Ri and Prentice (2017) estimated that the $\mathrm{N}_{2}$ fixation was about $340 \mathrm{Tg} \mathrm{N} \mathrm{yr}^{-1}$, which is almost 5 times larger than our estimates. In their study, BNF was determined by the plant $\mathrm{N}$ requirement across all biome types.

In our estimation, tropical forests significantly contribute to the total BNF, which is up to $18 \mathrm{~kg} \mathrm{Nha}^{-1} \mathrm{yr}^{-1}$. This result is highly related to the density of leguminous plants and the physical conditions in tropical areas (Crews, 1999). Our simulated results are comparable to the estimates of symbiotic $\mathrm{N}_{2}$ fixation from tropical evergreen $\left(5.5-16 \mathrm{~kg} \mathrm{Nha}^{-1} \mathrm{yr}^{-1}\right)$ and deciduous forests $\left(7.5-30 \mathrm{~kg} \mathrm{~N} \mathrm{ha}^{-1} \mathrm{yr}^{-1}\right.$ ) (Reed et al., 2011). Barron et al. (2010) directly measured $\mathrm{N}_{2}$-fixing root nodules across lowland tropical forests, and their observations also showed large variation among individual trees. For a mature forest matrix, the average value was around $10 \mathrm{~kg} \mathrm{Nha}^{-1} \mathrm{yr}^{-1}$, but it could be as high as $200 \mathrm{~kg} \mathrm{Nha}^{-1} \mathrm{yr}^{-1}$ for some areas. Cleveland (2013) provided a similar estimate to ours (around $12 \mathrm{~kg} \mathrm{Nha}^{-1} \mathrm{yr}^{-1}$ ) but higher values $\left(20-30 \mathrm{~kg} \mathrm{Nha}^{-1} \mathrm{yr}^{-1}\right)$ in their earlier studies (Cleveland et al., 1999). Sullivan et al. (2014) analyzed humans' impact on tropical $\mathrm{N}$ fixation and, depending on forest ages, found that fixation was $5.7 \mathrm{~kg} \mathrm{~N} \mathrm{ha}^{-1} \mathrm{yr}^{-1}$ with a range from 1.2 to $14.4 \mathrm{~kg} \mathrm{~N} \mathrm{ha}^{-1} \mathrm{yr}^{-1}$, which is lower than our estimates.

For temperate and boreal forests, we estimated that BNF fixation is $2.1-18 \mathrm{~kg} \mathrm{Nha}^{-1} \mathrm{yr}^{-1}$. The existing BNF estimates from the literature also show a large uncertainty for those forest ecosystems. For instance, the LM3V-N model (Gerber et al., 2009) suggested that the $\mathrm{N}$ input to forests was less than $5 \mathrm{~kg} \mathrm{Nha}^{-1} \mathrm{yr}^{-1}$. But their model also estimated that, in moist forests, the uptake of $\mathrm{N}$ could be $30-80 \mathrm{~kg} \mathrm{Nha}^{-1} \mathrm{yr}^{-1}$. Deluca et al. (2002) reported that 


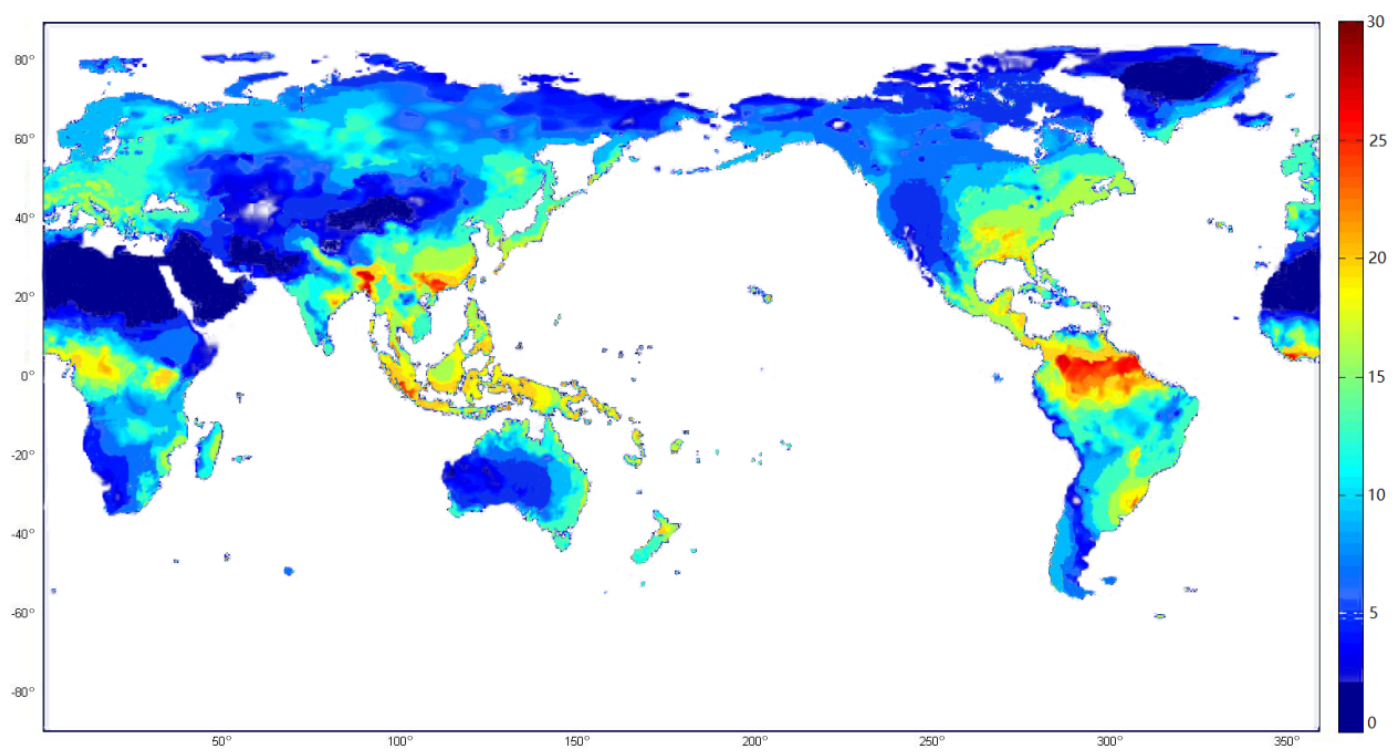

Figure 3. Simulated spatial distribution of BNF rates $\left(\mathrm{kg} \mathrm{N}_{2} \mathrm{ha}^{-1} \mathrm{yr}^{-1}\right)$ in natural terrestrial ecosystems from 1990 to 2000 by considering the BNF effects.

cyanobacterium and feather moss could act as a supplement to $\mathrm{N}_{2}$ fixation in boreal forests $\left(0.5 \mathrm{~kg} \mathrm{Nha}^{-1} \mathrm{yr}^{-1}\right)$, while the organic $\mathrm{N}$ accumulation could be $3 \mathrm{~kg} \mathrm{Nha}^{-1} \mathrm{yr}^{-1}$. For the forests in the northwest Rocky Mountains, $\mathrm{N}_{2}$ fixation amount is on average between 0.5 and $2 \mathrm{~kg} \mathrm{Nha}^{-1} \mathrm{yr}^{-1}$ (Clayton and Kennedy, 1985; Fahey et al., 1988), while the model of Kou-Giesbrecht and Menge (2019) estimated the $\mathrm{N}_{2}$ fixation rate to be $0-10 \mathrm{~kg} \mathrm{Nha}^{-1} \mathrm{yr}^{-1}$ for temperate forests, and 0 to $6 \mathrm{~kg} \mathrm{~N} \mathrm{ha}^{-1} \mathrm{yr}^{-1}$ for boreal forests.

There could be a number of reasons for our comparatively lower estimates. The most important one is that there is a considerable uncertainty in estimating the coverage of $\mathrm{N}_{2}$ fixing plants. High diversity in the distribution of legume plants highly influences the estimation of total plant coverage because our estimation was based on site-level experimental data. In order to improve our understanding, more investigation on legume plant distribution and associated data for $\mathrm{N}_{2}$ fixers is needed, especially in the central Asia, South America and Africa.

Large variations in BNF rates exist across terrestrial ecosystems spatially (Fig. 3). The global BNF spatial pattern is similar to other estimates (Cleveland et al., 1999; Xu-Ri and Prentice, 2017). The highest $\mathrm{N}_{2}$ fixation rate in tropical regions (more than $50 \%$ of the global terrestrial $\mathrm{N}_{2}$ fixation) is primarily due to their warm and moist soil conditions. Further, $\mathrm{N}_{2}$ fixed by human activities became increasingly influential in the past century (Galloway et al., 2002), especially in temperate regions due to their large human population. The anthropogenic $\mathrm{N}$ deposition contributed more to soil $\mathrm{N}$ than BNF did. As a result, soils became $\mathrm{N}$ rich, inhibiting BNF in temperate soils. This could explain why the potential
$\mathrm{N}_{2}$ fixation rate was high in temperate ecosystems but only contributed to $20 \%$ of the total fixation.

\subsection{Major controls on biological nitrogen fixation}

In our simulations, the $\mathrm{N}_{2}$ fixation was primarily influenced by soil temperature, moisture and soil nitrogen content. The highest $\mathrm{N}_{2}$ fixation rate in tropical ecosystems is consistent with our sensitivity analysis for temperature and soil moisture. The sensitivity analysis indicated that a $1-3{ }^{\circ} \mathrm{C}$ increase in temperature led to $7 \%$ increase in $\mathrm{N}_{2}$ fixation rate. The nitrogen cycle responds differently between different biomes and legume types. But in general, increasing temperature will accelerate processes in the $\mathrm{N}$ cycle. Soil moisture correlates with BNF in a similar way to temperature. A slight increase in precipitation $(10 \%)$ increased the nitrogenase activity. However, the response of $\mathrm{N}_{2}$ fixation to soil water stress is not as sensitive as that to the change in temperature. Xeric shrubland and savanna in dry tropical areas still contribute greatly to global $\mathrm{N}_{2}$ fixation, while the contribution of boreal forests, with low temperature, is much lower.

BNF is highly regulated by soil nitrogen content. Ndeficiency conditions usually favor BNF activities, for example, in xeric shrubland and savanna. Enhancing soil $\mathrm{N}$ content will decrease the $\mathrm{N}_{2}$ fixation rate, which is also consistent with our sensitivity analysis. It costs less energy for plants to take up $\mathrm{N}$ directly from soils rather than biologically fixing it from the atmosphere (Cannell and Thornley, 2000). However, there is an exception for some areas in tropical ecosystems. Many tropical soils are comparatively rich in nitrogen, but $\mathrm{N}_{2}$-fixing plants are still active to compensate for the nitrogen depletion due to the rapid $\mathrm{N}$ cycling (Pons et al., 2007). This explains why $\mathrm{N}$ fertilization inhibits the BNF in 
temperate ecosystems, but BNF is still active in N-rich soils in tropical ecosystems. In areas where the energetic cost exceeds the demand of $\mathrm{N}$, the BNF rate will be comparatively lower. Sullivan et al. (2014) suggested that there were lower rates of $\mathrm{BNF}$ in undisturbed mature forests and a higher rate in secondary forests, depending on the balance between $\mathrm{N}$ demand and energy consumption.

\subsection{Model limitation and future work}

The incorporation of BNF into TEM allows us to more adequately simulate nitrogen cycle from natural terrestrial ecosystems. However, there are several limitations in this study.

First, the current model ignores the effect of free-living BNF. Although symbiotic BNF is critical for most natural and seminatural ecosystems, asymbiotic organisms play an important role in extreme environments such as waterlogged soils and deserts. The importance of symbiotic BNF or fixation by leguminous plants may not be as significant as previously thought. Elbert et al. (2012) suggested that cryptogam contributed nearly half of BNF in terrestrial ecosystems, which was up to $49 \mathrm{Tg} \mathrm{Nyr}^{-1}$. In some tropical areas, the spatial $\mathrm{N}$ input from free-living bacteria even exceeds symbiotic input (Sullivan et al., 2014). In addition, legumes are not the only source of symbiotic BNF. Some fungi species have the ability to actively fix atmospheric nitrogen. But in most existing models, fungi or mycorrhizae symbioses are not considered due to the limited knowledge about their mechanisms of fixing $\mathrm{N}$ (Fisher et al., 2010). A more comprehensive model that covers various types of nitrogen fixation is needed.

Second, the BNF process in our model is calibrated with a limited amount of data, imposing a general set of parameters on all plant species and soil conditions within an ecosystem type. More observational data from natural terrestrial ecosystems are desirable to improve our model.

Third, it is difficult to isolate the $\mathrm{N}$ addition via natural processes from human activities. In the US, $20 \%-35 \%$ of annual $\mathrm{N}$ input into terrestrial ecosystems is human-related (Sobata et al., 2013). As a result, the quality of observational data varies from site to site, and some BNF data are only seminatural. The observational data are imperfect, which might also have biased our estimates through the model parameterization process.

\section{Conclusions}

This study developed a process-based biological nitrogen fixation model and coupled it with an extant biogeochemistry model. The model was evaluated with observed data for $\mathrm{N}_{2}$ fixation. The model was then extrapolated to the global natural terrestrial ecosystems. Our model estimates that biological nitrogen fixation in natural terrestrial ecosystems was
61.5 $\mathrm{Tg} \mathrm{N} \mathrm{yr}^{-1}$ during the last decade of the 20th century and the greatest fixation rate occurred in tropical regions. Soil temperature, rather than soil moisture and nutrient content, is the most dominant control on $\mathrm{N}_{2}$ fixation. Lacking the knowledge about the distribution of $\mathrm{N}_{2}$ fixing plants and their physiological features might have biased our estimates of biological nitrogen fixation at the global scale.

Data availability. Climate data including monthly cloudiness, precipitation, temperature and water vapor pressure are from the Climate Research Unit (CRU) http://www.cru.uea.ac.uk/data (Doherty et al., 1999; Jones, et al., 2012, last access: May 2017). Global vegetation data and soil data are available in Zhuang et al. (2003) and McGuire et al. (2001). The explicit spatial data on soil water $\mathrm{pH}$ from the ORNL gridded soil properties product (https://daac. ornl.gov/cgi-bin/dsviewer.pl?ds_id=546, Batjes, 2000, last access: May 2020) are based on the World Inventory of Soil Emission Potentials (WISE) database (Batjes, 2000). The global average carbon dioxide concentration is observed at NOAA's Mauna Loa Observatory. $\mathrm{N}$ deposition data are from the NADP monitor and CASTNET. The initial values of soil microbial carbon and nitrogen and the ratio of $\mathrm{C} / \mathrm{V} / \mathrm{N}$ at the global scale were from a compilation of global soil microbial biomass carbon, nitrogen and phosphorus data (https://doi.org/10.3334/ORNLDAAC/1264, Xu et al., 2014, last access: May 2017). The data presented in this paper can be accessed through our research website (http://www.eaps.purdue.edu/ebdl/, last access: May 2017).

Author contributions. QZ and TY designed the research. TY performed model simulations and data analysis. Both authors contributed to paper writing.

Competing interests. The authors declare that they have no conflict of interest.

Acknowledgements. This study is supported through projects funded by the NASA Land Use and Land Cover Change program (NASA-NNX09AI26G), the Department of Energy (DE-FG0208ER64599) and the NSF Division of Information and Intelligent Systems (NSF-1028291). Thanks to the Rosen Center for Advanced Computing (RCAC) at Purdue University for computing support.

Financial support. This research has been supported by the NASA Land Use and Land Cover Change program (grant no. NASANNX09AI26G), the Department of Energy (grant no. DE-FG0208ER64599), and the NSF Division of Information and Intelligent Systems (grant no. NSF-1028291).

Review statement. This paper was edited by Denise Akob and reviewed by two anonymous referees. 


\section{References}

Adams, M. A. and Attiwill, P. M.: Role of Acacia spp. in nutrient balance and cycling in regenerating Eucalyptus regnans $\mathrm{F}$. Muell. forests, I. Temporal changes in biomass and nutrient content, Aust. J. Bot., 32, 205-215, 1984.

Alexander, V. and Billington, M. M.: Nitrogen fixation in the Alaskan taiga, Forest ecosystems in the Alaskan taiga, Springer, New York, NY, 112-120, 1986.

Baker, T. G., Oliver, G. R., and Hodgkiss, P. D.: Distribution and cycling of nutrients in Pinus radiata as affected by past lupin growth and fertiliser, Forest Ecol. Manage., 17, 169-187, 1986.

Barron, A. R., Purves, D. W., and Hedin, L. O.: Facultative nitrogen fixation by canopy legumes in a lowland tropical forest, Oecologia, 165, 511-520, 2011.

Bate, G. C. and Gunton, C.: Nitrogen in the Burkea savanna, in: Ecology of Tropical Savannas, edited by: Huntley, B. J. and Walker, B. H., Springer-Verlag, New York, 498-513, 1982.

Batjes, N. H.: Global Data Set of Derived Soil Properties, 0.5Degree Grid (ISRIC-WISE), ORNL DAAC, Oak Ridge, Tennessee, USA, https://doi.org/10.3334/ORNLDAAC/546, 2000.

Belnap, J.: Nitrogen fixation in biological soil crusts from southeast Utah, USA, Biol. Fertil. Soils, 35, 128-135, 2002.

Blundon, D. J. and Dale, M. R. T.: Dinitrogen fixation (acetylene reduction) in primary succession near Mount Robson, British Columbia, Canada, Arct. Alp. Res., 22, 255-263, 1990.

Boote, K. J., Jones, J. W., and Hoogenboom, G.: Simulation of crop growth: CROPGRO model, Agr. Syst. Model. Simul., 18, 651692, 1998.

Boote, K. J., Hoogenboom, G., Jones, J. W., and Ingram, K. T.: Modeling nitrogen fixation and its relationship to nitrogen uptake in the in the CROPGRO model, in: Quantifying and Understanding Plant Nitrogen Uptake for Systems Modeling, edited by: Ma, L., Ahuja, L. R., and Bruulsema, T. W., CRC Press, Florence, USA, 13-46, 2008.

Boring, L. R. and Swank, W. T.: The role of black locust (Robinia pseudo-acacia) in forest succession, J. Ecol., 71, 749-766, 1984.

Bouniols, A., Cabelguenne, M., Jones, C. A., Chalamet, A., Charpenteau, J. L., and Marty, J. R.: Simulation of Soybean Nitrogen Nutrition for a Silty Clay Soil in Southern France, Field Crops Res., 26, 19-34, 1991.

Bowman, W. D., Schardt, J. C., and Schmidt, S. K.: Symbiotic N 2-fixation in alpine tundra: ecosystem input and variation in fixation rates among communities, Oecologia, 108, 345-350, 1996.

Breitbarth, E., Oschlies, A., and LaRoche, J.: Physiological constraints on the global distribution of Trichodesmium - effect of temperature on diazotrophy, Biogeosciences, 4, 53-61, https://doi.org/10.5194/bg-4-53-2007, 2007.

Bruijnzeel, L. A.: Nutrient input-output budgets of tropical forest ecosystems: a review, J. Trop. Ecol., 7, 1-24, 1991.

Bustamante, M. M. C., Medina, E., Asner, G. P., Nardoto, G. B., and Garcia-Montiel, D. C.: Nitrogen cycling in tropical and temperate savannas. Biogeochemistry, 79, 209-237, 2006.

Cabelguenne, M., Debaeke, P., and Bouniols, A.: EPICphase, A Version of the EPIC Model Simulating the Effects of Water and Nitrogen Stress on Biomass and Yield, Taking Account of Developmental Stages: Validation on Maize, Sunflower, Sorghum, Soybean, and Winter Wheat, Agric. Syst., 60, 175-196, 1999.
Cannell, M. G. R. and Thornley, J. H. M.: Modelling the components of plant respiration: some guiding principles, Ann. Bot.Lond., 85, 45-54, 2000.

Cech, P. G., Kuster, T., Edwards, P. J., and Olde Venterink, H.: Effects of herbivory, fire and $\mathrm{N}$ 2-fixation on nutrient limitation in a humid African savanna, Ecosystems, 11, 991-1004, 2008.

Chapin, D., Bliss, I. C., and Bledsoe, I. J.. Environmental regulation of nitrogen fixation in a high arctic lowland ecosystem, Can J. Bot., 69, 2744-2755, 1991.

Chen, M. and Zhuang, Q.: Modelling temperature acclimation effects on the carbon dynamics of forest ecosystems in the conterminous United States, Tellus B, 65, 19156, https://doi.org/10.3402/tellusb.v65i0.19156, 2013.

Christie, P.: Nitrogen in two contrasting Antarctic bryophyte communities, J. Ecol., 75, 73-93, 1987

Clayton, J. L. and Kennedy, D. A.: Nutrient Losses from Timber Harvest in the Idaho Batholith 1, Soil. Sci. Soc. Am. J., 49, 10411049, 1985.

Cleveland, C. C., Townsend, A. R., Schimel, D. S., Fisher, H., Howarth, R. W., Hedin, L. O., Perakis, S. S., Latty, E. F., Von Fischer, J. C., Elseroad, A., and Wasson, M. F.: Global patterns of terrestrial biological nitrogen $\left(\mathrm{N}_{2}\right)$ fixation in natural ecosystems, Global Biogeochem. Cy., 13, 623-645, 1999.

Cleveland, C. C., Houlton, B. Z., Neill, C., Reed, S. C., Townsend, A. R., and Wang, Y.: Using indirect methods to constrain symbiotic nitrogen fixation rates: a case study from an Amazonian rain forest, Biogeochemistry, 99, 1-13, 2010.

Cleveland, C. C., Houlton, B. Z., Smith, W. K., Marklein, A. R., Reed, S., Parton, W. J., Del Grosso, S., and Runing, S. W.: Patterns of new versus recycled primary production in the terrestrial biosphere, P. Natl. Acad. Sci. USA, 110, 12733-12737, 2013.

Corre-Hellou, G., Brisson, N., Launay, M., Fustec, J., and Crozat, Y.: Effect of root depth penetration on soil nitrogen competitive interactions and dry matter production in pea-barley intercrops given different soil nitrogen supplies, Field Crop. Res., 103, 7685, 2007.

Corre-Hellou, G., Faure, M., Launay, M., Brisson, N., and Crozat, Y.: Adaptation of the STICS intercrop model to simulate crop growth and $\mathrm{N}$ accumulation in pea-barley intercrops, Field Crop. Res., 113, 72-81, 2009.

Crews, T. E.: The presence of nitrogen fixing legumes in terrestrial communities: Evolutionary vs ecological considerations, New Perspectives on Nitrogen Cycling in the Temperate and Tropical Americas, Springer, Dordrecht, 233-246, 1999.

Crisp, M., Cook, L., and Steane, D.: Radiation of the Australian flora: what can comparisons of molecular phylogenies across multiple taxa tell us about the evolution of diversity in presentday communities?, Philos. T. R. Soc. B, 359, 1551-1571, 2004.

DeLuca, T., Zackrisson, O., Nilsson, M., and Sellstedt, A.: Quantifying nitrogen-fixation in feather moss carpets of boreal forests, Nature, 419, 917-920, 2002.

Doherty, R. M., Hulme, M., and Jones, C. G.: A gridded reconstruction of land and ocean precipitation for the extended tropics from 1974 to 1994, Int. J. Climatol., 19, 119-142, 1999.

DuBois, J. D. and Kapustka, L. A.: Biological nitrogen influx in an Ohio relict prairie, Am. J. Bot., 70, 8-16, 1983.

Eckersten, H., Geijersstam, L. A., and Torssell, B.: Modelling nitrogen fixation of pea (Pisum sativum L.), Acta. Agr. Scand. B.-S. P., 56, 129-137, 2006. 
Eisele, L., Schimel, D. S., Kapustka, L. A., and Parton, W. J.: Effects of available $\mathrm{P}$ and $\mathrm{N}: \mathrm{P}$ ratios on non-symbiotic dinitrogen fixation in tallgrass prairie soils, Oecologia, 79, 471-474, 1989.

Elbert, W., Weber, B., Burrows, S., Steinkamp, J., Büdel, B., Andreae, M. O., and Pöschl, U.: Contribution of cryptogamic covers to the global cycles of carbon and nitrogen, Nat. Geosci., 5, 459-462, 2012.

Fahey, T. J., Yavitt, J. B., Pearson, J. A., and Knight, D. H.: The nitrogen cycle in lodgepole pine forests, southeastern Wyoming, Biogeochemistry, 1, 257-275, 1985.

Fahey, T. J., Yavitt, J. B., and Joyce, G.: Precipitation and throughfall chemistry in Pinus contorta spp. latifolia ecosystems, southeastern Wyoming, Can. J. Forest Res., 18, 337-345, 1988.

Fisher, J. B., Sitch, S., Malhi, Y., Fisher, R. A., Huntingford, C., and Tan, S.-Y.: Carbon cost of plant nitrogen acquisition: A mechanistic, globally applicable model of plant nitrogen uptake, retranslocation, and fixation, Global Biogeochem. Cy., 24, GB1014, https://doi.org/10.1029/2009GB003621, 2010.

Galloway, J. N., Schlesinger, W. H., Levy, H., Michaels, A., and Schnoor, J. L.: Nitrogen fixation: Anthropogenic enhancementenvironmental response, Global Biogeochem. Cy., 9, 235-252, 1995.

Galloway, J. N., Cowling, E. B., Seitzinger, S. P., and Socolow, R. H.: Reactive nitrogen: too much of a good thing?, AMBIO: A Journal of the Human Environment, 31, 60-64, 2002.

Galloway, J. N., Dentener, F. J., Capone, D. G., Boyer, E. W., Howarth, R. W., Seitzinger, S. P., Asner, G. P., Cleveland, C. C., Green, P. A., Holland, E. A., Karl, D. M., Michaels, A. F., Porter, J. H., Townsend, A. R., and Vorosmarty, C. J: Nitrogen cycles: past, present, and future, Biogeochemistry, 70, 153-226, 2004.

Gerber, S., Hedin, L. O., Oppenheimer, M., Pacala, S. W., and Shevliakova, E.: Nitrogen cycling and feedbacks in a global dynamic land model, Global Biochemical. Cy., 24, GB1001, https://doi.org/10.1029/2008GB00333, 2010.

Goosem, S. and Lamb, D.: Measurements of phylloshpere nitrogen fixation in a tropical and two sub-tropical rainforests, J. Trop. Ecol., 2, 373-376, 1986.

Granhall, U., and Lid-Torsvik, V.: Nitrogen fixation by bacteria and free-living blue-green algae in tundra areas, in: Fennoscandian Tundra Ecosystems, edited by: Wielgolaski, F. E., Part I, Plants and Microorganisms, Spring-Verlag, New York, 305-315, 1975.

Grove, T. S. and Malajczuk, N.: Nodule production and nitrogen fixation (acetylene reduction) by an understorey legume (Bossiaea laidlawiana) in Eucalyptus forest, J. Ecol., 80, 303-314, 1992.

Gruber, N. and Galloway, J. N.: An Earth System Perspective of the Global Nitrogen Cycle, Nature, 451, 293-296, 2008.

Gundale, M. J., Nilsson, M., Bansal, S., and Jaderlund, A.: The interactive effects of temperature and light on biological nitrogen fixation in boreal forests, New Phytol., 194, 453-463, 2012.

Hardy, R. W. F., Holsten, R. D., Jackson, E. K., and Burns, R. C.: The acetylene-ethylene assay for $\mathrm{N}_{2}$ fixation: laboratory and field evaluation, Plant Physiol., 43, 1185-1207, 1968.

Hardy, R. W. F., Burns, R. C., and Holsten, R. D.: Applications of the acetylene-ethylene assay for measurement of nitrogen fixation, Soil Biol. Biochem., 5, 47-81, 1973.

Harvey, A. E., Larsen, M. J., Jurgensen, M. F., and Jones, E. A.: Nitrogenase activity associated with decayed wood of living northern Idaho conifers, Mycologia, 81, 765-771, 1989.
Heath, B., Sollins, P., Perry, D. A., and Cromack Jr., K.: Asymbiotic nitrogen fixation in litter from Pacific Northwest forests, Can J. Forest Res., 18, 68-74, 1988.

Hendrickson, O. Q.: Asymbiotic nitrogen fixation and soil metabolism in three Ontario forests, Soil Biol. Biochem., 22, 967-971, 1990.

Hendrickson, O. Q. and Burgess, D.: Nitrogen-fixing plants in a cutover lodgepole pine stand of southern British Columbia, Can J. Forest Res., 19, 936-939, 1989.

Holzworth, D. P., Huth, N. I., deVoil, P. G., Zurcher, E. J., Herrmann, N. I., McLean, G., and Moore, A. D.: APSIM-evolution towards a new generation of agricultural systems simulation, Environ. Modell. Softw., 62, 327-350, 2014.

Houlton, B. Z., Morford, S. L., and Dahlgren, R. A.: Convergent evidence for widespread rock nitrogen sources in Earth's surface environment, Science, 360, 58-62, 2018.

Huss-Danell, K.: Nitrogen fixation by Stereocaulon paschale under field conditions, Can J. Botany, 55, 585-592, 1977.

Jarrell, W. M. and Virginia, R. A.: Soil cation accumulation in a mesquite woodland: sustained production and long-term estimates of water use and nitrogen fixation, J. Arid Environ., 18, 51-58, 1990.

Johnson, H. B. and Mayeux, H. S.: Prosopis glandulosa and the nitrogen balance of rangelands: extent and occurrence of nodulation, Oecologia, 84, 176-185, 1990.

Jones, P. D., Lister, D. H., Osborn, T. J., Harpham, C., Salmon, M., and Morice, C. P.: Hemispheric and large-scale land surface air temperature variations: an extensive revision and an update to 2010, J. Geophys. Res., 117, D05127, https://doi.org/10.1029/2011JD017139, 2012.

Jordan, C. W., Caskey, W., Escalante, G., Herrera, R., Montagnini, E., Todd, R., and Uhl, C.: The nitrogen cycle in a Terra Eirme rain forest on Oxisol in the Amazon Territory of Venezuela, Plant Soil, 67, 325-332, 1983.

Kapustka, L. A. and DuBois, J. D.: Dinitrogen fixation by cyanobacteria and associative rhizosphere bacteria in the Arapaho Prairie in the Sand Hills of Nebraska, Am. J. Bot., 74, 107113, 1987.

Kou-Giesbrecht, S. and Menge, D.: Nitrogen-fixing trees could exacerbate climate change under elevated nitrogen deposition, Nat Commun., 10, 1493, https://doi.org/10.1038/s41467-019-094242, 2019

Layzell, D. B., Rainbird R. M., Atkins, C. A., and Pate, J. S.: Economy of photosynthate use in N-fixing legume modules: observations on two contracting symbioses, Plant Physiol., 64, 888-891, 1979.

LeBauer, D. S. and Treseder, K. K.: Nitrogen limitation of net primary productivity in terrestrial ecosystems is globally distributed, Ecology, 89, 371-379, 2008.

Lee, Y. Y. and Son, Y.: Diurnal and seasonal patterns of nitrogen fixation in analnus hirsuta plantation of central Korea, J. Plant Biol., 48, 332-337, 2005.

Lepper, M. G. and Fleschner, M.: Nitrogen fixation by Cercocarpus ledifolius (Rosaceae) in pioneer habitats, Oecologia, 27, 333338, 1977.

Lett, S. and Michelsen, A.: Seasonal variation in nitrogen fixation and effects of climate change in a subarctic heath, Plant Soil, 379, 193-204, 2014. 
Levy, H., Moxim, W. J., and Kasibhatla, P. S.: A global threedimensional time-dependent lightning source of tropospheric $\mathrm{NO}_{x}$, J. Geophys. Res.-Atmos., 101, 22911-22922, 1996.

Ley, R. E. and D'Antonio, C. M.: Exotic grass invasion alters potential rates of $\mathrm{N}$ fixation in Hawaiian woodlands, Oecologia, 113, 179-187, 1998.

Lindemann, W. C. and Glover, C. R.: Nitrogen fixation by legumes. New Mexico State University, Cooperative Extension Service, New Mexico State University, College of Agricultural, Consumer, and Environmental Sciences 2003.

Luken, J. O. and Fonda, R. W.: Nitrogen accumulation in a chronosequence of red alder communities along the Hoh River, Olympic National Park, Washington, Can. J. Forest Res., 13, 1228-1237, 1983.

Maheswaran, J. and Gunatilleke, I. A. U. N.: Nitrogenase activity in soil and litter of a tropical lowland rain forest and an adjacent fernland in Sri Lanka, J. Trop. Ecol., 6, 281-289, 1990.

Marino, D., Frendo, P., Ladrera, R., Zabalza, A., Puppo, A., ArreseIgor, C., and González, E. M.: Nitrogen fixation control under drought stress. Localized or systemic?, Plant Physiol., 143, 1968-1974, 2007.

May, D. E. and Webber, P. J.: Spatial and temporal variation of vegetation and its productivity on Niwot Ridge, Colorado, in: Ecological Studies in the Colorado Alpine, a Festschrift for John W. Mart, edited by: Halfpenny, H., 35-62, Institute for Arctic and Alpine Research, Univ. of Colorado, Boulder, Colorado, 1982.

Melillo, J. M., McGuire, A. D., Kicklighter, D. W., Moore III, B., Vorosmarty, C. J., and Schloss, A. L.: Global climate change and terrestrial net primary production, Nature, 363, 234-240, https://doi.org/10.1038/363234a0, 1993.

Mitchell, T. D. and Jones, P. D.: An improved method of constructing a database of monthly climate observations and associated high-resolution grids, Int. J. Climatol., 25, 693-712, 2005.

Montanez, A., Danso, S. K. A., and Hardarson, G.: The effect of temperature on nodulation and nitrogen fixation by five Bradyrhizobium japonicum strains, Appl. Soil Ecol., 2, 165-174, 1995.

Morford, S. L., Houlton, B. Z., and Dahlgren, R. A.: Increased forest ecosystem carbon and nitrogen storage from nitrogen rich bedrock, Nature, 477, 78-81, https://doi.org/10.1038/nature10415, 2011.

Mus, F., Crook, M. B., Garcia, K., Costas, A. G., Geddes, B. A., Kouri, E. D., and Udvardi, M. K.: Symbiotic nitrogen fixation and the challenges to its extension to nonlegumes, Appl. Environ. Microbiol., 82, 3698-3710, 2016.

Nohrstedt, H. Ö.: Biological activity in soil from forest stands in Central Sweden, as related to site properties, Microb. Ecol., 11, 259-266, 1985

O'Connel, A. M. and Grove, T. S.: Seasonal variation in $\mathrm{C} 2 \mathrm{H} 2$ reduction $\left(\mathrm{N}_{2}\right.$-fixation) in the litter layer of eucalypt forests of south-western Australia, Soil Biol. Biochem., 19, 135-142, 1987.

Omari, K., Mubyana, T., Matsheka, M. I., Bonyongo, M. C., Veenendaal, E., and Musil, C. F. Flooding and its influence on diazotroph populations and soil nitrogen levels in the Okavango Delta, S. Afr. J. Bot., 70, 734-740, 2004.

Permar, T. A. and Fisher, R. F.: Nitrogen fixation and accretion by wax myrtle (Myrica cerifera) in slash pine (Pinus elliottii) plantations, Forest Ecol. Manag., 5, 39-46, 1983.
Pons, T. L., Perreijn, K., Van Kessel, C., and Werger, M. J.: Symbiotic nitrogen fixation in a tropical rainforest: ${ }^{15} \mathrm{~N}$ natural abundance measurements supported by experimental isotopic enrichment, New Phytol., 173, 154-167, 2007.

Reed, S. C., Cleveland, C. C., and Townsend, A. R. Functional ecology of free-living nitrogen fixation: a contemporary perspective, Annu. Rev. Ecol. Evol. S., 42, 489-512, 2011.

Robertson, G. P. and Rosswall, T.: Nitrogen in West Africa: The tropical cycle, Ecol. Monogr., 56, 43-72, 1986.

Rundel, P. W., Nilsen, E. T., Sharifi, M. R., Virginia, R. A., Jarrell, W. M., Kohl, D. H., and Shearer, G. B.: Seasonal dynamics of nitrogen cycling for a Prosopis woodland in the Sonoran Desert, in: Nitrogen Cycling in Ecosystems of Latin America and the Caribbean, Springer, Dordrecht, 343-353, 1982.

Rylr, G. J. A., Powell, C. E., and Gordon, A. J.: Th respiratory costs of nitrogen fixation in soybean, cowpea and white clover, I. Nitrogen fixation and the respiration of the nodulated root, J. Expt. Bot., 30, 145-153, 1979.

Sánchez-Diaz, M.: Adaptation of legumes to multiple stresses in Mediterranean-type environments, Options Méditerranéennes, 45, 145-151, 2001.

Schlesinger, W. H., Gray, J. T., Gill, D. S., and Mahall, B. E.: Ceanothus megacarpus chaparral: a synthesis of ecosystem processes during development and annual growth, Bot. Rev., 48, 71-117, 1982.

Schrire, B. D., Lewis, G. P., and Lavin, M.: Biogeography of the Leguminosae, Legumes of the world, 21-54, 2005.

Schwintzer, C. R.: Nonsymbiotic and symbiotic nitrogen fixation in a weakly minerotrophic peatland, Am. J. Bot., 70, 1071-1078, 1983.

Sharpley, A. N. and Williams, J. R.: EPIC Erosion/Productivity Impact Calculator: 1. Model Documentation, USA Department of Agriculture Technical Bulletin No. 1768, USA Government Printing Office, Washington DC, 1990.

Shearer, G. and Kohl, D. H.: $\mathrm{N}_{2}$-fixation in field settings: estimations based on natural ${ }^{15} \mathrm{~N}$ abundance, Funct. Plant Biol., 13, 699-756, 1986.

Sheridan, R. P.: Nitrogenase activity by Hapalosiphon flexuosus associated with Sphagnum erythrocalyx mats in the cloud forest on the volcano La Soufriere, Guadeloupe, French West Indies, Biotropica, 23, 134-140, 1991.

Skujinš, J., Tann, C. C., and Börjesson, I.: Dinitrogen fixation in a montane forest sere determined by $15 \mathrm{~N} 2$ assimilation and in situ acetylene-reduction methods, Soil Biol. Biochem., 19, 465-471, 1987.

Sobota, D. J., Compton, J. E., and Harrison, J. A.: Reactive nitrogen inputs to US lands and waterways: how certain are we about sources and fluxes?, Front. Ecol. Environ., 11, 82-90, 2013.

Sonesson, M., Jonsson, S., Rosswall, T., and Rydén, B. E.: The Swedish IBP/PT Tundra Biome Project Objectives-PlanningSite, Ecol. Bull., 30, 7-25, 1980.

Sprent, J. I.: The effects of water stress on nitrogen-fixing root nodules, New Phytol., 71, 443-450, 1972.

Sprent, J. I., Ardley, J., and James, E. K.: Biogeography of nodulated legumes and their nitrogen-fixing symbionts, New Phytol., 215, 40-56, 2017.

Srivastava, A. K. and Ambasht, R. S.: Soil moisture control of nitrogen fixation activity in dry tropical Casuarina plantation forest, J. Environ. Manage., 42, 49-54, 1994. 
Stedman, D. H. and Shetter, R.: The global budget of atmosphere nitrogen species, in: Trace Atmospheric Constituent: Properties, Transformations and Fates, edited by: Schwartz, S. S., John Wiley, New York, 411-454, 1983.

Stewart, W. D. P., Sampaio, M. J., Isichei, A. O., and SylvesterBradley, R.: Nitrogen fixation by soil algae of temperate and tropical soils, in: Limitation and potentials for biological nitrogen fixation in the tropics, edited by: Dobreiner, J., Burris, R. H., and Hollaender, A., Basic Life Sciences, Plenum Press, New York, Vol. 10, 41-63, 1978.

Sutton, M. A., Mason, K. E., Sheppard, L. J., Sverdrup, H., Haeuber, R., and Hicks, W. K.: Nitrogen deposition, critical loads and biodiversity, Springer Science and Business Media, https://doi.org/10.1007/978-94-007-7939-6, 2014.

Sullivan, B. W., Smith, W. K., Townsend, A. R., Nasto, M. K., Reed, S. C., Chazdon, R. L., and Cleveland, C. C.: Spatially robust estimates of biological nitrogen $(\mathrm{N})$ fixation imply substantial human alteration of the tropical $\mathrm{N}$ cycle, P. Natl. Acad. Sci. USA, 111, 8101-8106, 2014.

Sylvester-Bradley, R., Oloveira, L. A., Podesta Filho, J. A., and St John, T. V.: Nodulation of legumes, nitrogenase activity-fixing Azospirillum app. in representative soils of Central Amazonia, Proc. Int. Lupin Conf., 157-173, 1980.

Thornley, J. H. M.: Simulating grass-legume dynamics: a phenomenological submodel, Ann. Bot.-Lond., 88, 905-913, 2001.

Vitousek, P. M.: Potential nitrogen fixation during primary succession in Hawaii Volcanoes National Park, Biotropica, 26, 234240, 1994

Vitousek, P. M. and FIeld, C. B.: Ecosystem constraints to symbiotic nitrogen fixers: A simple model and its implications, Biogeochemistry, 46, 179-202, 1999.

Vitousek, P. M., Menge, D. N., Reed, S. C., and Cleveland, C. C.: Biological nitrogen fixation: rates, patterns and ecological controls in terrestrial ecosystems, Philos. T. R. Soc. B, 368, 20130119, https://doi.org/10.1098/rstb.2013.0119, 2013.

Voisin, A. S., Salon, C., Jeudy, C., and Warembourg, F. R.: Symbiotic $\mathrm{N}_{2}$ fixation activity in relation to $\mathrm{C}$ economy of Pisum sativum $L$. as a function of plant phenology, J. Exp. Bot., 54, 2733-2744, 2003.

Voisin, A. S., Bourion, V., Duc, G., and Salon, C.: Using an ecophysiological analysis to dissect genetic variability and to propose an ideotype for nitrogen nutrition in pea, Ann. Bot.-Lond., 100, 1525-1536, 2007.

Weber, M. G. and Van Cleve, K.: Nitrogen dynamics in the forest floor of interior Alaska black spruce ecosystems, Can J. Forest Res., 11, 743-751, https://doi.org/10.1139/x81-106, 1981.

Wheatley, R. E. and Sprent, J. I.: Legume Nodulation: A Global Perspective, edited by: Sprent, J. I., Chichester, UK, WileyBlackwell, ISBN 97818405181754, 200 pp., 2009.
Williams, J. R. and Sharply, A. N.: EPIC-Erosion Productivity Impact Cacalator, Model Documentation, US Department of Agriculture Technical Bulletin, 235 pp., 1768.

Woodmansee, R. G. and Wallach, L. S.: Effects of fire regimes on biogeochemical cycles, Terr. Nitr. Cy. Ecol. Bull., 33, 649-669, 1981.

Wu, L. and McGechan, M. B.: Simulation of nitrogen uptake, fixation and leaching in a grass/white clover mixture, Grass Forage Sci., 54, 30-41, 1999.

Xu, X., Thornton, P. E., and Potapov, P.: A Compilation of Global Soil Microbial Biomass Carbon, Nitrogen, and Phosphorus Data, ORNL DAAC, Oak Ridge, Tennessee, USA, https://doi.org/10.3334/ORNLDAAC/1264, 2014.

$\mathrm{Xu}-\mathrm{Ri}$ and Prentice, I. C.: Modelling the demand for new nitrogen fixation by terrestrial ecosystems, Biogeosciences, 14, 2003 2017, https://doi.org/10.5194/bg-14-2003-2017, 2017.

$\mathrm{Yu}, \mathrm{T}$. and Zhuang, Q.: Quantifying global $\mathrm{N}_{2} \mathrm{O}$ emissions from natural ecosystem soils using trait-based biogeochemistry models, Biogeosciences, 16, 207-222, https://doi.org/10.5194/bg-16207-2019, 2019.

Zhuang, Q., Romanovsky, V. E., and McGuire, A. D.: Incorporation of a permafrost model into a large-scale ecosystem model: Evaluation of temporal and spatial scaling issues in simulating soil thermal dynamics, J. Geophys. Res.-Atmos., 106, 33649-33670, 2001.

Zhuang, Q., McGuire, A. D., O’neill, K. P., Harden, J. W., Romanovsky, V. E., and Yarie, J.: Modeling soil thermal and carbon dynamics of a fire chronosequence in interior Alaska, J. Geophys. Res.-Atmos., 107, 8147, https://doi.org/10.1029/2001JD001244, 2002.

Zhuang, Q., McGuire, A. D., Melillo, J. M., Clein, J. S., Dargaville, R. J., Kicklighter, D. W., Myneni, R. B., Dong, J., Romanovsky, V. E., Harden, J., and Hobbie, J. E.: Carbon cycling in extratropical terrestrial ecosystems of the Northern Hemisphere during the 20th Century: A modeling analysis of the influences of soil thermal dynamics, Tellus B, 55, 751-776, 2003.

Zhuang, Q., McGuire, A. D., Melillo, J. M., Clein, J. S., Dargaville, R. J., Kicklighter, D. W., and Hobbie, J. E.: Carbon cycling in extratropical terrestrial ecosystems of the Northern Hemisphere during the 20th century: a modeling analysis of the influences of soil thermal dynamics, Tellus B, 55, 751-776, 2011.

Zhuang, Q., Lu, Y., and Chen, M.: An inventory of global N2O emissions from the soils of natural terrestrial ecosystems, Atmos. Environ., 47, 66-75, 2012

Zhuang, Q., Chen, M., Xu, K., Tang, J., Saikawa, E., Lu, Y., and McGuire, A. D.: Response of global soil consumption of atmospheric methane to changes in atmospheric climate and nitrogen deposition, Global Biogeochem. Cy., 27, 650-663, 2013. 